\title{
PIONEER
}

VOLUME 12, Issue 1, June 2020: 55 - 72

\section{FRANK'S CRITICISM TOWARD NAZISM AS SEEN FROM THE LIVES OF THE CHARACTERS IN THE DIARY OF A YOUNG GIRL}

\author{
Adriya Vitalya Gemilang \\ Universitas Sarjanawiyata Tamansiswa Yogyakarta \\ vitaliaisme@gmail.com
}

\begin{abstract}
This research is analyzing a diary by Anne Frank. It tells the readers about the lives of the Jews during the Nazi occupation. The diary describes the experiences of the Jews in order to survive during Nazism. It tells how the Jews are discriminated and suffered by Nazism. Anne Frank describes their everyday life vividly and in honest way which brings the readers to understand their experiences without experience it. The objective of this research is to identify Frank's criticism toward Nazism as seen from the lives of the characters. In order to accomplish the objectives, the library research is used since many data and theories are collected from some books. In order to analyze the problem, the writer employs the sociocultural-historical approach. It is used to identify criticism toward Nazism. The result of the analysis shows that there is Frank's criticism toward Nazism in the description of the lives of the characters under the Nazis occupation. Through her diary, Anne Frank criticizes the discrimination, the lack of education, the hunger, the chaos and the mass killing during the reign of Nazism in the Netherlands.
\end{abstract}

Keywords: Frank's criticism, nazism, the diary of a young girl

\section{INTRODUCTION}

History has a function to awaken human about the process of revolution and society development in time dimension, which is to build perspective and historical consciousness in discovering the past, the present, and the future. History has recorded many events since the civilization began, from bad events to the good one. According to Hudson, as stated in An Introduction to the Study of Literature, literature is a vital record of what men have seen in life, what they have seen in life, what they have experience of it, what they have thought and felt about those aspects of it which have the most immediate and permanent interest for all of us (1958: 10). Thus, we can understand the history of certain time by reading literature, understanding the experience of certain people without experience it.

Since the beginning of history, men have fought against other men. Any struggle in which two large groups try to destroy or conquer each other is a war. War has been 
going on somewhere in the world nearly all the time. One of the wars which will never be forgotten is the Second World War. It killed more persons, cost more money, damaged more property, affected more people, and probably caused more changes than any other war in history. The war began when Germany attacked Poland on September 1, 1939. Under the leadership of Adolf Hitler, they attacked Poland to increase their power, to gain the supremacy of the Aryan. The German people, who later called themselves as Nazis, believed that they were the super-men. They were destined to rule the world. According to them, one of the obstacles which prevent them from ruling the world was the Jews. To exterminate the Jews, they conduct a massive killing for Jews which later people know as Holocaust. They found that Holocaust was more effective and efficient to do rather than to selecting the people which not related to Jews (http://en.wikipedia.org/wiki/Holocaust\#Etymology). The holocaust resulted with the death more than five million Jews. Adolf Hitler as the Fuehrer succeeded to conquer most of Europe nearly 5 years on his 12 years of dictatorship. After the fall of the Fuehrer, history has recorded many version of the Second World War; one of them is a diary which was written by a girl name Anne Frank.

Anne Frank was a young Jewish girl whose diary records the two years that her family spent in hiding to escape for the persecution of the German Nazis (Webster, 1995: 432). Their family lived at Germany before stayed at Netherlands. After Hitler won the election to be the Fuehrer, the political condition threat their life, they moved to Amsterdam where Otto Frank received an offer to start company. In there they found peace until the Germany invaded Netherlands on May 1940. The discrimination started, and the political policy of the Nazis forced his two daughters transferred from their first school to the Jewish Lyceum (http://en.wikipedia.org/wiki/Anne_Frank).

The reason why the diary is published, simply because Anne Frank heard a radio broadcast by Gerrit Bolkestein, a member of the Dutch government in exile. He said that when the war ended, he would create a public record of the Dutch people's oppression under German occupation. Anne started editing her writing, creating pseudonyms for the members of the house hold and the helpers in the hiding place (Frank, 1952: 205).

In the beginning she wrote the diary, it is just typical writing of a schoolgirl. She describes herself, her family, her friend, her school life, boys she flirted with and her 
favorite places. However, after the German undertaken the Netherlands, her diary described more closely on the relationship with the people who lived in the hiding place, the 'Secret Annex', translated from Het Achterhuis. The Secret Annex was a three-story space at the rear of the building that was entered from a landing above her father's office, the Opekta office. The Secret Annex was inhabited by eight people. The situation in the Secret Annex grew tenser when eight people forced to live under the same roof without any privacy and under the Nazi oppression. Reading from her diary, the reader will know the hard times they should maintain in order to live. Knowing how it feels to live as Jews under the Nazi regime.

Before the publication of the diary, Jan Romein wrote an article about the diary, he mentioned that the diary stammered out in a child's voice, embodies all the hideousness of fascism, more so than all the evidence at Nuremberg put together. The article attracted attention from publisher. After the publication of the diary in 1947, many responses arise. One of the responses was a play based upon the diary, by Frances Goodrich and Albert Hackett premiered in New York City on October 5, 1955 which later won a Pulitzer Prize for drama. Over the years, the popularity of the diary grew. Ilya Ehrenburg, a Soviet writer, commented on the diary; said one voice speaks for six million, the voice not of a sage or a poet but of an ordinary little girl. Nelson Mandela, after receiving a humanitarian award from the Anne Frank Foundation in 1994, said that he likened her struggle against Nazism to his struggle against Apartheid. He also said that these beliefs (Nazism and Apartheid) are patently false, and because they were, and will always be challenged by the likes of Anne Frank, they are bound to fail (http://en.wikipedia.org/wiki/Anne_Frank).

Based on the statements above, the topic "Criticism to Nazism" is chosen. It is worth discussing because from the topic, the reader will understand how the Nazis treated the Jews, how they exploited and killed the Jews. Understanding how they try to survive, understanding their experience without experiencing it, and also to awaken our conscience about how single ambitious purpose to conquer the world could destroy almost the entire race. Therefore, this study will further discuss about Frank's criticism toward Nazism as seen in the Diary. 


\section{REVIEW OF LITERATURE}

\section{Theory of Character and Characterization}

According to E.M. Forster in Aspects of the Novel, character is divided into 'flat 'and 'round' characters. A flat character is built around 'a single idea or quality' and is presented in outline and without much individualizing detail, so can be adequately described in a single phrase or sentence. A flat character is characterized by one or two traits; Forster named it as 'flat', because we see only one side on him. A round character is complex in temperament and motivation and presented with subtle particularity. We remember him in connection with great scenes, that is to say, we do not remember him easily, because he waxes and wanes and has many facets like a human being, thus he is as difficult to describe with any adequacy as a person in real life, and like most people, and he is capable of surprising us (1974: 46-51).

Abrams in A Glossary Literary Terms (1981: 20) says that character can be divided based on the importance. He categorizes characters into major character and minor character. Major character can be called a central character. It is a character that is relevant to every event in the story and usually the events cause some changes either in him or in our attitude toward him. Meanwhile minor characters are characters who appear in certain setting, and they are necessary to become the background for the major characters. Their roles are less important than the major character because they are not fully developed characters and their functions in a story are only to support the development of the major characters.

Rohrberger and Woods (1971: 20-21) differentiate characters according to their function in the story. They are protagonist and antagonist. A protagonist is the most important character or the central character of the story. He or she is the one to whom all events in the story have relevance. Meanwhile antagonists are the other major characters of a story that oppose the protagonist. They are involved in conflicts with the protagonist.

Perrine (1974: 68) states that the characterization must also consider three principles:

1. The character must be consistent in their behavior.

2. The character must be clearly motivated in whatever they do, especially when there are many changes in their behavior. 
3. They must be lifelike or plausible. They must be neither paragons of virtue nor monsters of evil nor an impossible combination of contradictory traits.

According to Abrams (1981: 21), characterization could be presented in two ways:

1. Showing (also called the dramatic method), the author merely presents his characters talking and acting and leaves the reader to infer what motives and disposition lay behind what they say and do.

2. Telling the author himself intervenes authoritative in order to describe, and often to evaluate, the motives and dispositional qualities of his characters.

\section{Theory of Setting}

According to Holman and Harmon, there are four elements making up a setting. They are:

1. The actual geographical location, its topography, scenery, and such physical arrangements as the location of the windows and doors in a room.

2. The occupation and daily manner of living of the character.

3. The time or period in which the action takes place.

4. The general environment of the characters, for example, religious, mental, moral, social and emotional conditions through which the people in the narrative move (1986: 465).

Setting according to Abrams, can be noticed in a limited sense and in large sense. Setting seen in a limited sense means that the setting refers to the general place, a particular physical location where the story occurs, and the historical time showing when the story take place. In a large sense, the setting refers to the social circumstances; those are situations, conditions, and environments where the characters live (1981: 175). Van De Laar and Schoonderwoed say that the action of the characters in the novel needs place and time as we do in real life. The settings make the action full of varieties and support the action (1963: 172). Murphy state that setting has great effect upon the characters' personalities, actions, and way of thinking (1972: 141).

According to Stanton, setting is the background of the actions, the real world where the characters occur. He states that setting can be the real background; in this case place, can be the time of day or year, or it also can be the climate on the historical period. Commonly, many literary works give their setting in a descriptive passage, and this makes some readers have difficulties to understand it, but it will be clearer and 
more specific in the second reading. In many stories, the setting produces a definite emotional tone or mood that surrounds the characters; the actual geographical location, its topography, scenery, and such (1965: 18-19).

\section{The Relation between Literature and Society}

According to Rene Wellek and Austen Warren in their book Theory of Literature, literature is a social creation that employs language as its medium. Literature represents life or social reality (1956: 94). The most common approach to the relation of literature and society is the study of works of literature as social document and pictures of social reality. Literature as social document and pictures of social reality has ability to record the features of society (1965: 95). The society in wider sense comprehends not merely peoples and their classes but also their customs, conventions, beliefs and values, their legal institutions, religious and cultural, and their physical environment (Langland, 1984: 6).

There are three classifications that can underline the relation between literature and society. First, there is the sociology of the writer and the profession, institution of literature, the whole question of the economic basis of literary production, the social provenance and status of the writer, his social ideology, which may find expression in extra-literary pronouncement and activities. Second, there is the problem of the social content, the implications and social purpose of the work of literature it selves. Lastly, there are the problems of the audience and actual social influence of literature (Wellek and Warren, 1956: 95-96). The three classifications are the concepts to question how far literature relates to society.

From the statement above, it could be stated that literature is a medium to learn certain custom or tradition at a certain place or certain time. Also a source of history for modern readers who interested in foreign society as a result from reading a literary work such as drama, novel, short story, and poetry (1956: 102-104).

\section{Theory of Nazism}

Nazism believes that Germans, the Aryan, are the creator of the modern civilization. Thus, they are superiors. Basically, Nazism is just another form of Fascism. Fascism is a form of government which centers all power in a single party. Fascism is highly nationalistic, almost into extreme nationalism. It worshiping the purity of a nation, so a plurality will look like treason. Some other country, or some other group 
within the country, is usually picked out to serve as the enemy and made to appear as the cause of all misfortunes. Hitler is a fascist. After their defeat in the First World War, Germany suffer a great lost and humiliation from the winning country. Germany must pay for the damage caused by the war. The consequence is hyper-inflation which then resulted in poverty and unemployed people. After the Weimar Republic failed to prevail over the crisis, in the late 1933 Hitler built the most powerful and destructive regime in the history of modern world, the Nazi (Ebenstein, 1971: 53).

According to Hugh Purcell (2004: 39), the blue print of the Nazism is an autobiography and Hitler's political statement, Mein Kampf. Hitler wrote the book when he was in Landsberg jail after his unsuccessful attempt to revolt for the Weimar Republic. In the Mein Kampf, Hitler directed the fear and the hatred to Jews. Also, he stated his beliefs and his ideas for Germany's future, including his plan to conquer much of Europe. Hitler wrote that the Germans were the highest species of humanity on earth. They would stay pure by avoiding marriage to Jews and Slavs. Hitler blamed the Jews for all evils of the world. (Jenks, 1971: 238)

Hitler made the Germans believe that Jews are corruptor and communist who make them suffer. In short, the Jews are the cause of all their suffering. Nazism also believes that to build their union of all Germans in a Greater Germany, they must eliminating parasitic races, which specially Jews.

\section{METHOD}

The method of the study which the writer applied was a library research. In library research, the data were collected from books and other writings which needed to support the topic of the study as the materials. This study uses the socioculturalhistorical approach to analyze the topic.

Beside the primary data of the study, which of course is the diary itself, the writer needed the secondary data to answer the problem formulation. They were: $A$ Glossary of Literary Terms (Abrams, 1981), Aspects of the Novel (Forster, 1974), Reading and Writing about Literature (Rohrberger and Woods, 1971), A handbook to Literature (Holman and Harmon, 1996), Encyclopedia of Literature (Wellek and Warren, 1956), The World Book Encyclopedia (Field Enterprises Educational Corporation, 1971), Literature: Structure, Sound and Sense (Perrine, 1971), Understanding Unseen (Murphy, 1972), An Introduction to Fiction (Stanton, 1965), An 
Approach to English Literature (Laar \& Schoonderwoerd, 1957), A History of the Jews (Johnson, 1987), Fascism (Purcell, 2004), The Tragedy of Children under Nazi Rule (Sosnowski, 1962). However, to get more and more information about the author, the work, and any information related to Nazism, the writer has browsed many websites. Some data were taken by considering their relevance, validity, accuracy, and appropriateness. Those sources helped the writer to get a better understanding of the theories, and then applied it to the study.

There were some steps the writer has done in doing the research. The first step was reading the book to get a deep understanding of the diary and also to find the appropriate topic to discuss. The second step was finding problem and formulating research questions to guide the study. The next step was collecting the supporting sources for the research. Then, the writer conducted the analysis by answering the research questions using the knowledge that is gained from the relevant source. The last step was drawing a conclusion.

\section{FINDINGS AND DISCUSSION}

\section{Frank's Criticism toward Nazism as Seen from the Lives of the Characters}

This part will discuss about the criticism to Nazism. The first part describes how the Nazi has affected the characters' life. The Nazi succeed in destroying the life of the eight people in the Secret Annexe. Actually, all of them are decent and good people, but the reign of Nazism that already reach Netherlands turn their lives drastically. Their peaceful life turns into difficult and dangerous. Even though Anne still mentions about their optimism of the future, the unstable condition change them for being optimistic into pessimistic, waiting for the war to end. The good news about the restore of political situation after the attempt to kill Hitler on July 21, 1944, makes them optimistic in the last months in the Secret Annexe. However, what happen later is far beyond their expectation. The Nazis discover their hiding. After the Allies won the war, what is left from the Secret Annexe is only the diary that records all their experiences during their hiding. Otto Frank who is saved from the Holocaust decided to publish the book. The rest of his family died in the concentration camp. Through her diary, Anne criticizes Nazism for the suffering they made. Several times, Anne mentioned in her diary that they are suffer only because their race, Jews. 
Anne Frank criticizes the discrimination to the Jews. The discrimination exists in every aspects of their life. After Nazism reach the Netherlands, Hitler sets rules that discriminate the Jews and then eventually alienated them from their nation, to evict them. One of the rules is the Jews obligated to wear a yellow star badge. Hitler stated rules that obligate the Jews to wear a badge for their identity. It is one of the steps of the Holocaust program. The badge is mean to alienate the Jews from their nation. In her diary, Anne mentioned an event related to the yellow star badge. On her entries at July 9, 1942, Anne told the process of their family moving from their home to the Secret Annexe. Because of the rules from the Nazis that discriminate the Jews, they are not allowed to use the public transport. Therefore, they walked in the pouring rain and no one who saw them offering a lift. Everyone else was afraid to help because the yellow star badge. Helping them will endanger their life. From the event, the effect of the yellow star badge is clearly described.

According to Johnson, from September 1941, all Jews aged six or over had to wear a Star of David, black with Yellow background, as large as the palm of the hand, with the word Jude in the middle. This was an identification system, which made it much easier to detect Jews breaking the countless regulations, turned the entire German nation into a police force and participation in the persecution, and demoralized the Jews themselves (1987: 489).

In the Netherlands, the Jews must wear the yellow star badge if they were in the public place since May 1942. It is stated that the Jews must wear a yellow star with the word "Jew" printed on it, also they are banned to use the public transport (http://www.humboldt.edu/ rescuers/book/Strobos/Conditions.Holland.html). The badge make people recognize them as Jews and at the same time prevent them to give help. The consequence of that sign is they are afraid to be at the public place because there are the rule which alienated them or even worse, anyone can reported them to the Nazis if they do mistake. The Nazis would send them to the concentration camp and then lost their life with various ways. They risk their life by going outside.

The discrimination to the Jews is the result of the Anti-Semitism policy from Hitler. Anti-Semitism is a set of negative and sometimes hostile beliefs and prejudices regarding the Jews. Hitler used the Anti-Semitism as part of his propaganda. Hitler assumes that to achieve a purpose need a good motivation, thus he uses the Anti- 
Semitism as a motivator for the Germans. After the Weimar Republic failed to overcome the Great Depression which makes large number of unemployment and hunger, Hitler used the anger of the people to gain his purpose, to build Great Germany. He succeeded to aim their anger toward the Jews, who is accused as the cause of all their suffering. Hitler made them believe that a political change or the replacement of the Weimar regime would end the Great Depression. In January 30, 1933 Hitler become a chancellor. He succeeded to overthrow the Weimar regime then build power in Germany by an Anti-Semitic regime.

The discrimination toward the Jews is increasing along with the reign of Nazism in the Netherlands. The critical situation forced the Franks to hide in the Secret Annexe. The deportations of Jews out from Holland start on July 1942. Exactly at July 5, 1942, one day after the Franks receive a letter which is a notice to the member of the family to join the forced labor, they moved to the Secret Annexe. Since then until 1944, the Franks hide in the Secret Annexe in order to escape from the Nazis persecution. The Nazis issues new regulations for all the Jews in the Germany occupied country. Anne mentioned it in her diary about the regulation to Jews, which mean to evict them from their country.

Rauter, one of the German big shots, has made a speech. "All Jews must be out of the German occupied countries before July 1. Between April 1 and May 1, the province of Utrecht must be cleaned out [as if the Jews were cockroaches]. Between May 1 and June 1 the provinces of North and South Holland." These wretched people are sent to filthy slaughterhouses like a herd of sick, neglected cattle. (p.87)

The regulation issued as the next stage of the anti-Jewish policy in Germany and as a part of his Holocaust program. This stage is called as the internationalization. Hitler continues to spread his ideology outside Germany. He carried out the same step to the Netherlands as in Germany. He gradually eliminates the entire Jews role in the society, and then eventually deported them to the concentration camp. According to Johnson in A History of the Jews, Hitler's anti-Jewish policy was legalized by the introduction of Nuremberg Decrees on September 15, 1935. Later, they began to strip the Jews of their basic rights and beginning the process of separating them from the rest of the population. Anne mentions in her diary that after May 1940 is the beginning of the 
Jews' suffering. These are several regulations for the Jews, which Anne called AntiJewish decrees.

Jews must wear a yellow star, Jews must hand in their bicycles, Jews are banned from trams and are forbidden to drive. Jews are only allowed to do their shopping between three and five o'clock and then only in shops bear the placard "Jewish shop". Jews must be indoors by eight o'clock and can not even sit on their own gardens after that hour. Jews are forbidden to visit theaters, cinemas, and other places of entertainment. Jews may not take part in public sports. Swimming baths, tennis courts, hockey fields, and other sports grounds are all prohibited to them. Jews may not visit Christians. Jews must go to Jewish school, and many restrictions of a similar kind. (p.14)

According to Johnson in A History of the Jews, the Holocaust program is a program that has an aim to discriminate, exploited and then eventually kills the Jews. The program is aimed to kill the Jews along with its cultures, to eliminate the traces of Jews. Through the Holocaust program, to eliminate the Jews is a legal act.

The discrimination toward the Jews from the Nazis cost them their freedom and the worst their life. The Nazis stripped out all their rights, first their civil rights and finally their human rights. In her diary, Anne Frank wrote that Jews are suffered and discriminated, and they hope that someday the world will accept them as human, not only as the Jews.

We have been pointedly reminded that we are in hiding, that we are Jews in chains, chained to one spot, without any rights, but with thousand duties. We Jews mustn't show our feeling, must be brave and strong, must accept all inconveniences and not grumble, must do what is within our power and trust in God. Sometimes this terrible war will be over. Surely the time will come when we are people again, and not just Jews. (p.221)

She also criticizes the lack of education that they have after the Nazi reaches the Netherlands. In her diary, she always mentions about her wishes back to school after the war. Her optimism arises after hearing news of the invasion.

Oh, Kitty, the best part of the invasion is that I have the feeling that friends are approaching. 
Margot says, I may yet be able to go back to school in September or October (p. 260).

While they stayed at the Secret Annexe, they only get knowledge from books which are delivered by their protectors. Even though they live in hiding, they never waste their time. Every day Anne read different kinds of books to increase her knowledge. As a substitute for their disability to join the formal school, they join long distance courses to learn about various subjects. They are enlisted using the name of their protectors. The Nazi has forbid the Jews to enter the public school, worse they will lost their life if they are seen or known to be alive. There is an event which shows how a book can harm their life. She describes the event in her entries at August 10, 1943.

Dussel has indirectly endangered our lives. He actually let Miep bring a forbidden book for him, one which abuses Mussolini and Hitler. On the way she happened to be run into by an SS car. She lost her temper, shouted, "Miserable wretches" and rode on. It is better not to think of what might have happened if she had had to go to their headquarters (p. 116).

This is the only way they have in achieving their education as Jews. Even the Nazis forbid all the books about Jews, or rebellion against Nazism. The effect of Nazism in the education has already felt even before they stayed at the Secret Annexe. Because of its political policy, which banned all the Jews to have their education except in the Jewish school, Margot and Anne are forced to transfer from their first school in the Netherlands to Jewish Lyceum. Start from August 1941, Nazis declared regulation that Jewish children are banned from public and vocational schools (http://www.humboldt.edu/ rescuers/book/Strobos/Conditions.Holland.html).

Frank criticizes the Nazism for the hunger, which happens in the whole Netherlands. In the previous analysis, it is mentioned about the "food cycle". It is a term to describe the unstable condition of the food supply. It happens because the government use a voucher as the replacement of money to buy foods which only for non-Jews. The food supply also depends on the ability of their protectors to provide it. There was a time when Anne describes their needs of sufficient foods.

She made our mouths water. We, who get nothing but two spoonfuls of porridge for our breakfast and whose tummies were so empty that they were positively rattling, we, who got nothing but half-cooked spinach (to preserve the vitamins) and rotten 
potatoes day after day, we, who get nothing but lettuce, cooked or raw, spinach and yet again spinach in our hollow stomachs (p. 243).

Anne Frank also criticizes Nazism for the chaos that happens in the Netherlands. The chaos is varies in kind and places. The war between the Nazis and the Allies make them live in the middle of shooting and bombing. This is the first kind of chaos as the result of the Nazism. They could not live without worrying about when the air raid is starting, or the gun banging. They must be alerts all the time. There is an entry when Anne tried to describe the fear during the air raids.

It was high time, for we had not been upstairs five minutes when they began shooting hard, so much so that we went and stood in the passage. And yes, the house rumble and shook, and down came the bombs (p. 103).

How scared the ladies are during the air raids. For instance, on Sunday, when 350 British planes dropped half a million kilos of bombs on Ijmuiden, how the houses trembled like a wisp of grass in the wind (p. 205).

Besides living in the middle of the air raids and the shooting, Anne mentions the news about the chaos in the society condition. The prices soar, burglaries in all over Netherlands and the reports of missing people everyday.

Everyone deals in the black market, every errand boy has something to offer. Our baker's boy got hold of some sewing silk, 0.9 florin for a thin little skein, the milk man manages to get clandestine ration cards, the undertaker delivers the cheese. Burglaries, murders, and theft go on daily. The police and night watchmen join in just as strenuously as the professionals, everyone wants something in their empty stomachs and because wage increases are forbidden the people simply have to swindle. The police are continually on the go, tracing girls of fifteen, sixteen, seventeen and older who were reported missing every day (p. 240).

The chaos also comes in the form of the damaged buildings. As it stated in the first chapter, war always results in misery on humanity. The Second World War killed more persons, cost more money, damaged more property, affected more people, and probably caused more changes than any other war in history. The war between the Allies and the Nazis in the Netherlands cost many damages. Anne mentions news about the damaged that happen in Amsterdam on her entries at Monday, 19 July 1934. 
North Amsterdam was heavily bombed on Sunday. The destruction seems to be terrible. Whole streets lie in ruins, and it will take a ling time before all the people are dug out. Up till now there are two hundred dead and countless wounded; the hospitals are crammed. You hear of children lost in the smoldering ruins, looking for their parents. I shudder when I recall the dull droning rumble in the distance, which for us marked the approaching destruction (p. 102).

Nazism is also the cause of the chaos in the economic. The unstable condition causes the crumble of the economy. Thus, poverty is the consequence of the war. Poverty make them do anything without considering the penalty, their morale are decreasing. Besides the casualties, Anne Frank also mentioned about the attitude of the people in that moment.

Little children of 8 and 11 years break the windows of the people's homes and steal whatever they can lay their hands on. No one dares to leave his house unoccupied for five minutes, because if you go, your things go too....Morale among the population can't be good, the weekly rations are not enough to last for few days except the coffee substitutes (p. 206).

Thus, Anne criticizes Nazism for the chaos in their everyday life, in the society and economy, and the damaged of the buildings.

Anne Frank also criticizes the mass killing of the Jews conducted by the Nazis. Several times Anne mentioned in her diary that they were killed for being Jews.

Our many Jewish friends are being taken away by the dozen. These people are treated by the Gestapo without a shred of decency, being loaded into cattle trucks and sent to Westerbork, the big Jewish camp in Drente (p. 49).

After Hitler discriminated and alienated the Jews from their country, he continues to the next stage of the Holocaust program. He sent the Jews to the concentration camp to join the forced labor, or to be an experiment for the scientist and then finally to be slaughtered. The concentration camp was build to do the mass killing. There were more than 1000 camps. These camps were deliberately planned or extended for mass slaughter on an industrial scale. In these camps, there were gas chambers. The gas chamber was called a shower room, and the victims, taken in groups of twenty or thirty, were told they were to have a shower. They were sealed in, and then the doctor on duty gassed them. During their hiding, every day they heard news about missing 
people. The Nazis just dragged them from their house, and then no one knows about their existence. In Netherlands, as it mentioned in the diary, they sent a letter which is a notice to the Jews, inviting them to join the forced labor. The letter which is actually a notice for their death. The Nazis forced the Jews to work hard without sufficient food and shelter. The laborers were worked from dawn until dusk seven days a weeks, dressed in rags and fed on bread, watery soup, potatoes and sometimes meat scraps. Then, the forced laborers died because of fatigue and hunger. It was 'destruction through work' as the Nazis called it. Hitler regarded the war as his license for the Holocaust. No Jews was too young to die. All women arriving at the dead camps were shaved to the skin, the hair being packed up and sent to Germany. If a breast-fed baby was a nuisance during the shaving, a guard simply smashed its head against the wall.

Anne describes what she heard about the condition in the concentration camp in her entry on 9 October 1942.

Westerbork sounds terrible: only one washing cubicle for a hundred people and not nearly enough lavatories. There is no separate accommodation. Men, women, and children all sleep together. One hears of frightful immortality because of this; and lot of the women, and even girls, who stay there any length of time, are expecting babies. It is impossible to escape; most of the people in the camp are branded as inmates by their shaven heads and many by their Jewish appearance... We assume that most of them are murdered. The English radio speaks of their being gassed. (p. 50)

The mass killing in all over Nazis occupied land that Anne always been heard and criticize, finally happens to herself. Anne Frank died in Auschwitz with her sister, Margot. The Nazi discovered their hiding a few days from Anne Frank last entries. She died only a few months before the Allies liberated the camps. Auschwitz was one of the most infamous Nazi concentration camps during the Second World War. It was opened in June 1940, in the town of Auschwitz in Poland, about 30 miles from Krakow. In June 1941, it became an extermination center when four huge gas chambers were installed. Rudolf Hess, who directed the camp for more than three years, testified at the Nuremberg trials that more than 2,5 million persons were executed at Auschwitz and 500,000 starved to death. Most of the victims were Jews from German- controlled countries (Jenks, 1971: 868). 
According to Woolf, by the end of the Second World War, the Nazis had deported 107,000 Jews out of Holland. Of these, only 5000 survived to return home following the war and 30,000 managed to survive in hiding or by other means. Thus, over $75 \%$ of Holland's Jews perished at the hands of the Nazis (http://www.webster.edu/ woolflm/netherlands.html).

\section{CONCLUSION}

By reading The Diary of a Young Girl: Anne Frank, we can experience the daily life of Anne Frank and the rest of the members of the Secret Annexe. Otto Frank, Edith Frank, Margot Frank, Anne Frank, Mr. \& Mrs. Van Daan, Peter Van Daan, and Mr. Dussel life have drastically change after the Nazis reach the Netherlands. They are living with fear while they hide in the Secret Annexe. They are afraid that anytime they could loose their life. They are worried the Nazis will discover their hiding or the building will collapse by bombs from the air raids. Besides those worries, they are also having difficulties to fulfill their daily needs even though they have enough money. The war makes the prices soars and the limited food supply. They are also having difficulties to continue their education, the Nazis forbids all books and education for the Jews. Fortunately, they have their protectors to overcome all their difficulties during their hiding in the Secret Annexe. The protectors are friends of Otto Frank at the office. They supply all the daily needs, including food, clothes, and books of knowledge. Margot, Anne and Peter are able to continue their education by joining long distance course using the names of their protectors. The atmosphere in the Secret Annexe become tense as the effect of their disability to be socially interacts with the outside world. They only communicate with the outside world by hearing the news from the radio or their protectors. Anne also mentions that some time they all become pessimistic of the possibility to have a normal life again, but after hearing the news of the invasion from the Allies and the attempt to kill Hitler, they become optimistic for their future. However, what happen later is far beyond their expectation. The Nazis discovered the Secret Annexe only three days after Anne's last entries on her diary. Otto Frank is the only person who managed to survive from the Nazi persecution.

Nazism has changed their life drastically, their life turn into miserable and dangerous life. They lives in difficulties since Nazism reach Netherlands. Hitler, the Fuehrer of Germany, uses the Anti-Semitism as the part of his propaganda. Anti- 
Semitism itself is a set of negative and sometimes hostile beliefs and prejudices regarding Jews. Thus, the purpose of Nazism is to eliminate the Jews and other races which considered lower than the Aryan or the Germans. They conduct Holocaust to persecute the Jews and to build the Great Germany. During the Second World War, the Nazis spread miseries for the Jews.

Anne Frank's diary is one of many documents, which records the brutality of Nazism to the Jews. Through the description from the lives of the characters at the Secret Annexe in the diary of Anne Frank, it can be comprehend how the Nazis held their Holocaust program. Thus, also with her writing in her diary, Anne Frank criticizes Nazism. Anne Frank criticizes the discrimination to the Jews, the lack of education, the hunger, the chaos, and the mass killing of the Jews conducted by the Nazis.

As the conclusion, Nazism as an ideology whose main purpose is to eliminates the Jews succeeded to reach its goal. The ambition of Hitler to build the Great Germany has killed more than 6 million people. They were killed because they are Jews. Anne Frank who lives during the Nazis persecution is able to describe vividly the effect of Nazism to the Jews in Netherlands. Her diary contains a lot of criticism toward Nazism. Even though she cannot survive the persecution, she gets what she want, to go on living after death. With the publication of the diary she will always be alive and remind us all of the Nazism brutality.

\section{REFERENCES}

Abrams, M. H. (1981). A Glossary of Literary Terms. New York: Holt, Rinehart and Winston, Inc.

Frank, A. (1952). The Diary of a Young Girl: Anne Frank. New York: Doubleday \& Company, Inc.

Holman, C. H. \& Harmon, W. (1996). A handbook to Literature. New York: Macmilan Publishing Company.

Hudson, W. H. (1958). An Introduction to the Study of Literature. London: Morrison \& Gibb, Ltd.

Johnson, P. (1987). A History of the Jews. New York: Harper \& Row Publishers.

Laar, E. V. D. \& N. Schoonderwoerd. (1957). An Approach to English Literature. S' Hertogenbosch: L. C. G. Malmberg.

Langland, E. (1984). Society in the Novel. California: The University of North California Press 
Murphy, M. J. (1972). Understanding Unseens: An Introduction to English Poetry and the English Novel for Overseas Student. London: George Allen and Unwin Ltd.,

Perrine, L. (1965). Literature: Structure, Sound and Sense $2^{\text {nd }}$ ed part 1. New York: Harcourt, Brace, Jovanovich Inc.

Rohrberger, M. \& Samuel H. W. Jr. (1971). Reading and Writing about Literature. New York: Random House Inc.

Stanton, R. (1965). An Introduction to Fiction. New York: Holt Rinehart and Winston, Inc.

Sosnowski, K. (1962). The Tragedy of Children under Nazi Rule. Warszawa: Western Press Agency.

Wellek, R \& Warren, A. (1956). Theory of Literature. New York: Harcourt, Brace \& World Inc.

Woolf, L. M. Survival and Resistance: The Netherlands under Nazi Occupation $<\mathrm{http} / /$ www.webster.edu/ woolflm/Netherlands.html> ( 31 October 2006).

- - Jewish Situation under the German Occupation of the Netherlands $<$ http://www.humboldt.edu/ rescuers/book/Strobos/Conditions.Holland.html> (31 October 2006).

<http://en.wikipedia.org/wiki/Anne_Frank> (31 October 2006).

<http://www.ess.uwe.ac.uk/genocide/reviewsh34html> (31 October 2006).

<http://en.wikipedia.org/wiki/Anne_Frank> (31 October 2006).

<http://www.ess.uwe.ac.uk/genocide/reviewsh34html> (31 October 2006). 